\title{
Effect of activated water treatment plant solid waste sludge on waste water for irrigation
}

\author{
Abdou El Nagar ${ }^{1}$, Mobarak H Ali ${ }^{2}$ 'Mohamed K fatah and Abdou ${ }^{2,}$ Ezzat A El Fadaly ${ }^{2}$ \\ 1- Environmental Studies and Researches Institute; Egypt \\ 2- Environmental Studies and Research Institute, University of Sadat City, Egypt
}

\begin{abstract}
This study aims to reusing of normal sludge from water treatment plants for waste water treatment for agricultural use. Normal and acid activated sludge with different acid concentration is used for the treatments. $1,2,4 \mathrm{~N} \mathrm{HCl}$ is the activator. $1-20 \mathrm{~g} / \mathrm{lt}$ from sludge are used. The best effect of water treatment plant sludge(WTPS) in waste water treatment, due to using of acid activated sludge $(1 \mathrm{~N} \mathrm{HCL}, 2 \mathrm{~N} \mathrm{HCl})$ in waste water treatment was $3 \mathrm{~g} / \mathrm{lt}$ at room temperature.It was observed that,activation of sludge affected on their particles properties; size, structure and density that leads to increase of; surface area and adsorption efficiency, $\mathrm{pH}$ decreased from 9.6 to 8.3 then raised to 9,BOD as well as COD decreased from78/129 to $30 / 10$ with addition of raw or acidified sludge till $2 \mathrm{~N} \mathrm{HCl}$ while the effect of $4 \mathrm{~N}$ $\mathrm{HCl}$ is $500 / 100$, Ammonia decreased by $14-33 \%$ with addition of sludgeand $20 \%$, Heavy metals; $\mathrm{Al}+3$ and $\mathrm{Fe}+3$, reduction is observed in this study. These uptakes of them is up to $75 \%$ to $95 \%$ turbidity (1 NTU) where it was improved till $99 \%$; Phosphate uptake is $19-60 \%$ with addition of raw sludge and acidified with $1 \mathrm{~N}$ and $2 \mathrm{~N}, \mathrm{HCl}$; while at $4 \mathrm{~N}, \mathrm{HCl}$ the uptake is $19 \%$, conductivity and TDS increased together with $8 \%$ approximately but it was observed, conductivity and TDS decreased. The influence of mixed salt solutions percolation on the media that elevated exchangeable sodium levels at low concentrations cause dispersion and swelling of the clay minerals and consequently a reduction in hydraulic conductivity of the water solution.wateranalysed with reference COD, BOD, Turbidity, conductivity, TDS, $\mathrm{pH}$, Ammonia, Phosphate and aluminum, Iron according to international standards.
\end{abstract}

The result indicates to the best using of normal sludge was $5 \mathrm{~g} / \mathrm{lt}$, at room temperature and acid activated sludge $(1 \mathrm{~N} \mathrm{HCL}, 2 \mathrm{~N} \mathrm{HCl})$ in waste water treatment was $3 \mathrm{~g} / \mathrm{ltat}$ room temperature. We can recommended that the reuse of raw water clarification sludge was the best compensation to get suitable COD, BOD, Turbidity, conductivity, TDS, pH, Ammonia, Phosphate and heavy metals removal in waste water and preserving the environment.

Key words: : water pollution, Environmental impacts, human health, waste water treatment, activated sludge

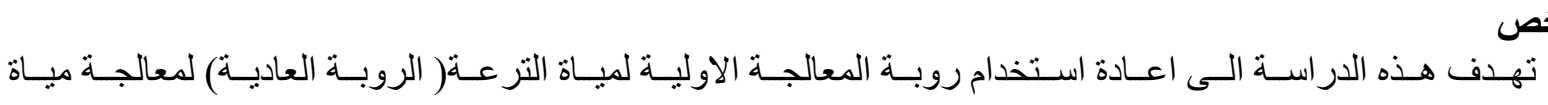

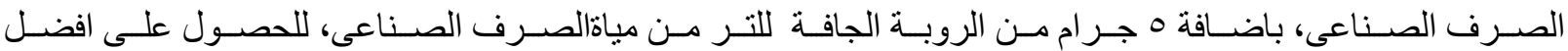

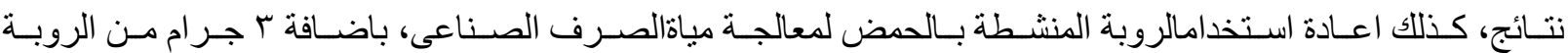

$$
\begin{aligned}
& \text { للتر من مياة الصرف الصناعى، للحصول على افضل نتائج . }
\end{aligned}
$$

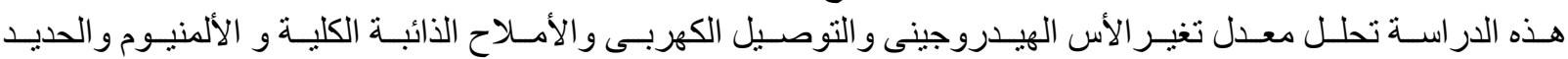

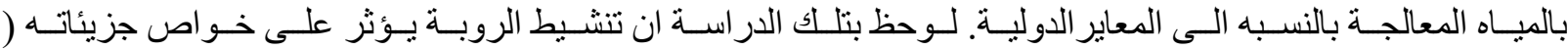

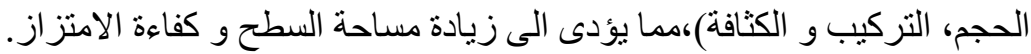




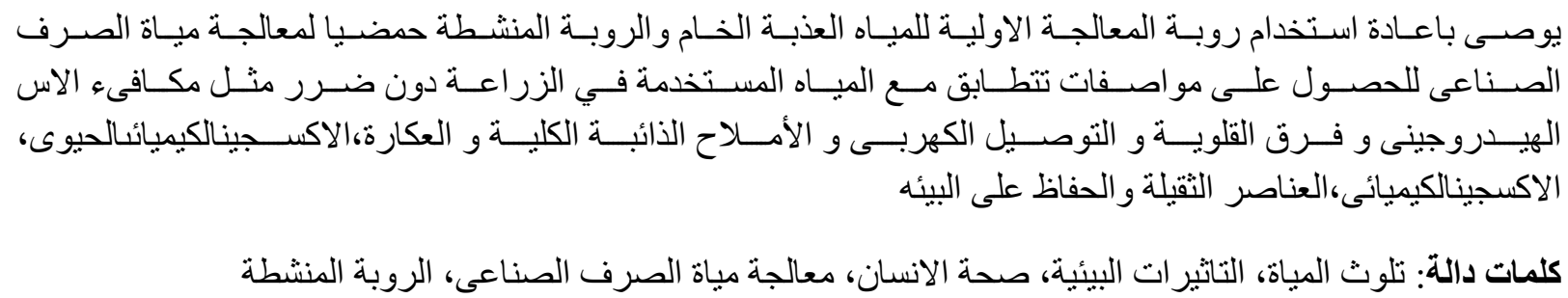

\section{INTRODUCTION}

Global demand for water has been increasing proportionally with life and human growth. The world's population is growing by roughly 81 million people each year and expected reach 10 billion at 2057 with duplication numbers through the last decade. Egypt's population is expected to increase to 160 million in 2050.https://www.worldometers.info/world-population/. Therefore, globally demand for freshwater is increasing by 64 billion cubic meters a year (Gerbens, D. et al,2009)(1).Several water treatment processes create large amounts of alum sludge around the world. Economically sustainable and environment friendly management of alum sludge must be focused. Water treatment plants process produce sludge $1-3 \%$ by volume of the raw water through the treatment process. The solid content of thickened sludge is typically $2-4 \%$, and mechanically dewatered sludge varied between $17 \%$ and $23 \%$ as well as disposal of one ton costs 130 . There is little information on alum sludge production and disposal data. Sludge production statistics, costs and other associated information are generally limited even in recent literature(Blakemore et al., 1998)(2).

During these treatment processes large quantity residues or wastes are generated known as water treatment sludge(WTS) and a typical WTP produces about 100,000 ton/year of sludge whereas, on a global scale, available literature estimates that at present the daily production of sludge exceeds 10,000 ton. The WTS is of environmental concern and requires careful consideration if it is to be managed in an environmentally acceptable and sustainable manner.

Most of the water treatment plants in Egypt discharges the sludge into the river Nile without treatment leading to accumulative rise of aluminum concentrations and aquatic organisms in water. Aluminum is related to Alzheimer, children mental retardation, and heavy metals accumulation. These effects ensured imperative sustainable safe management of the sludge(Deng, and Zhao, 2015)(3).

Global industrial growth is related to human population as well as environmental pollution and climate change. Domestic, agricultural and industrial are the main sector consumed water resources and has exacerbated the challenges relating to availability, quality, and purity of water resources. Pollutants such as oxygendemanding substances, pathogens, nutrients, inorganic, and synthetic organic chemicals have beenlisted as potential contaminants in municipal wastewater (Tchobanoglous, G. et al,2012)(4).

Oxygen demanding substances such as ammonia pose potential dangers to aquatic life. Pathogens are carried into the ground water through sewage sourcing from 
industrial waste, storm runoff, and municipal sources. Nutrients such as carbon, nitrogen, and phosphorus are found in large quantities in agricultural waste water. If not treated properly, the large amounts of nutrients, primarily phosphorus, and nitrogen cause nutrient enrichment resulting in algae growth and eutrophication(Diamantis, v. et al, 2018) (5).

Biochemical oxygen demand (BOD) represents the amount of oxygen consumed by bacteria and other microorganisms while they decompose organic matter under aerobic (oxygen is present) conditions at a specified temperature.COD (chemical oxygen demand) indicates all oxidizable materials but provides no information on their biodegradability (Rosen, M. and Kunjappu, J, 2012)(6).

The sludge generated in WTPs is composed of organic and inorganic matter in the solid, liquid and gaseous states, whose composition varies in terms of its physical, chemical and biological characteristics disperse suspension with a wide range of rough disperse or even colloidal particles(Maiden, Pet . ,al, 2015)(7).

The dispersed or colloidal particles present in the raw water are agglomerated and settled down by the aid of chemicals known as coagulants; the chemicals used frequently create a considerable part of the sludge. Commonly used coagulants are aluminum salts $\left(\mathrm{Al}_{2} \quad(\mathrm{SO} 4)_{3} .18 \mathrm{H} 2 \mathrm{O}\right)$, ferric ion salts(e.g., $\left.\mathrm{FeCl}_{3} .6 \mathrm{H} 2 \mathrm{O}\right)$, and ferrous iron salts (e.g., $\mathrm{FeCl}_{2}, \mathrm{FeSO}_{4} \$ 7 \mathrm{H} 2 \mathrm{O}$ )(Sales et al., 2011); thus the WTS consists of varying concentrations of microorganisms, organic and suspended matter, coagulant products and chemical elements(Ruiz-Rosa, I.,al, 2015)(8).

Water works sludge is mainly from the sedimentation tank or clarifier sludge water and filter back wash water, and amounts to about $47 \%$ of the total amount of water. Common options of sludge management include land filling, application to farmland and forestry and thermal treatment, e.g. incineration. Agricultural use of sewage sludge has been the traditional approach for sludge treatment; however, sludge is rich of metals, pathogens and low concentration antibiotics, which are of primary concern in limiting its potential use as a fertilizer and may cause secondary pollution problems in the environment(Liu, C., et al, 2018)(9).

Sludge is carbonaceous in nature, and its conversion to adsorbents might be a promising way, not merely to ecofriendly solve the problem of secondary pollution, but also to allow its reuse in water treatment applications. In previous studies, many researcher save used sewage and industrial sludge to prepare sludge-based adsorbents (SBAs) which are low-cost alternatives of activated carbon and have wide and efficient applications in adsorbing different dyes, organic compounds, heavy metals and even in removing gaseous contaminants. Alum salts using in water purification is technically an aluminum sulphate with general composition of $\mathrm{MAl}\left(\mathrm{SO}_{4}\right) 12 \mathrm{H}_{2} \mathrm{O}$ where is either ammonium or potassium ion. When alum salts were added to raw turbid water sources during drinking water purification process, aluminum ions were hydrolyzed into aluminum hydroxide which is a precipitate(Degaard, H., et al, 2018)(10). 
Organic matter and other water insoluble impurities in the raw water can be absorbed by aluminum hydroxide precipitates after the flocculation-clarification process during drinking water treatment process. Alum sludge is principally formed as gelatinous amorphous structures and consists of organic and suspended matter, inorganic matter, various microbial consortia, coagulant products and chemical substances The quality of alum sludge is highly dependent on the source of water quality, quality and purity of the alum and other treatment chemicals used, such as powdered activated carbon for taste and odor control, and polymers used to aid flocculation There-fore, physicchemical properties of alum sludge could vary widely depending the above factors(Soulsby, R. et al, 2013)(11).

Alkaline treatments of sodium hydroxide and calcium hydroxide gave the highest aluminum removal efficiency at the $\mathrm{pH}$ ranges of 11.4-11.8and 11.2-11.6, respectively. Liquid ion exchange processes and membrane-based separation techniques have also been studied for the aluminum recovery in the literature (Benidickson, J.and, Beychok, M, 2011)(12).

Alum sludge is considered as one of the major adsorbent for pollutant removal from waste water treatment plants and it can eliminate a wide range of heavy metals from the waste water by augmenting adsorption and chemical precipitation. Amorphous nature of the hydroxyl-Al present and its high surface area are the main parameters responsible for the elevated metal adsorption capacities. These adsorption properties of the alum sludge can be used to remove heavy metal pollutants(Ghosh,A. et al, 2016)(13).

Adsorptive treatment of heavy metals using non-conventional adsorbents such as agricultural and industrial solid wastes has been reported. Exchange, oxidation, adsorption, membrane filtration, and electrochemical treatment technologies are involved. However, most of these techniques have drawbacks such as inadequate removal efficiency, production of large amounts of sludge, and need for high capital and running costs and high technology. Thus these methods are not viable for small industries in developing countries. Adsorption process involving the use of solid adsorbents has been widely studied for heavy metal removal. While activated carbon is the most commonly used adsorbent, efforts have been made to use low-cost sorbents for heavy metal removal (Natarajan R and Manivasagan R , 2016)(14).

Agricultural and agronomic utilization of alum sludge can be rated as a beneficial use for crop production as well an effective sludge management method. Alum sludge application as a soil amendment was first reported by Russell (1975), and afterward numerous investigations have been carried out to appraise the impact of alum sludge on soil and ecosystems. Three key factors can be considered when alum sludge is utilized as a soil ameliorant and those are the best possible efficient utilization rate with the minimum environmental cost (Angin, I.et al, 2012)( 15). 
The aim of the present paper is utilization of water treatment plants sludge in improving of waste water to agricultural application.

\section{Materials and methods:}

Nubaria Power Station for electricity production is located in Kom Hamada Town west of Alexandria. It produces $2250 \mathrm{MW} /$ hour. The company takes raw water from Nubaria canal and treated it outside and inside the boiler. The outside treatment includes clarification, filtration, and ion exchange.

Nubaria Power Station for electricity production using coagulant compounds that carry a charge opposite aluminum to form a floc of aluminum hydroxide in raw water and waste water. So, in this study reusing of pretreatment sludge for heavy metals removal from waste water.

The main constituting minerals of raw materials and the developed crystalline phases in the processed fired bodies were determined, utilizing an XRD spectrometer equipment by (PW 1700, Philips Co, Holland). A $0.5 \mathrm{gm}$ of the finely ground material (-200 mesh) was packed in a sample holder and scanned by a copper target $(\lambda=1.54$ Á) at a rate of $1 \% \mathrm{~min}$, using a Ni filter. A plot of the intensity against $2 \theta$ values from 4 to 80 was obtained. The main peaks were identified according to the standard card number.

Different methods were used for analyses, according to ASTM, American Society for testing and material (2002), and Standard Methods for the Examination of Water and Wastewater' (Standard Methods), 19 th edition, 1995. Specific apparatus for determination, $\mathrm{AL}+3, \mathrm{Fe}+3, \mathrm{pH}$, TDS, Conductivity, Turbidity, BOD, COD.

$\mathrm{pH}$ values of all water samples were measured by using $\mathrm{pH}$ meter( Stdc27310,Canicsa Co, Germany), Its value was determined according to method described in Standard Methods (2001). Conductivity was measured for all water samples by using conductivity meter(Usted4510,Orion3Star Co,Singapor).. Aluminum and iron determined using a spectrophotometer (Cecil 2040, Perkin Elmer Co, Germany).

Aluminum was determined by dissolving requisite amount of aluminum ammonium sulphate in distilled water and standardized, Hydrochloric and nitric acid and the mixture was heated gently 1-ml of perchloric acid (sp, Gr. 1.70) was added to the solutions and evaporated until strong fuming. The solution was cooled to room temperature. The soluble salts were dissolved in demonized water. The solution was filtered into a 10-ml calibrated flask, the absorption spectrum, select the optimum wavelength to use for all subsequent absorbance measurements(Li.Z, L. N. et al,2007)( 16).

Complex of iron (II) and 1,10-phenanthroline, C12H8N2. This complex absorbs light in the visible region rather strongly with a maximum absorbance occurring around $510 \mathrm{~nm}$. Prepare a standard iron solution containing about $0.0500 \mathrm{~g}$ of iron per 
$500 \mathrm{~mL}$ by first calculating the required amount of pure ferrous ammonium sulfate [Fe(NH4)2(SO4)2C6H2O].

Weigh out the sample using an analytical balance and dissolve this in about 200 $\mathrm{mL}$ of deionized water containing $5.0 \mathrm{~mL}$ of $6 \mathrm{M} \mathrm{H} 2 \mathrm{SO} 4$ in a $500-\mathrm{mL}$ volumetric flask. Dilute with water to the mark and mixthoroughly by inverting the stoppered flask several times. Transfer about $50 \mathrm{~mL}$ of this stock solution to a labeled plastic transfer $5.00 \mathrm{~mL}$ of this standard iron solution to a $100-\mathrm{mL}$ volumetric flask.

Add $10 \mathrm{~mL}$ of acetate buffer $(5.0 \mathrm{M} \mathrm{HC} 2 \mathrm{H} 3 \mathrm{O} 2,0.5 \mathrm{M} \mathrm{NaC} 2 \mathrm{H} 3 \mathrm{O} 2)$. Add $10 \mathrm{~mL}$ of freshly prepared $10 \% \mathrm{w} / \mathrm{v}$ hydroxylamine hydrochloride $(\mathrm{NH} 2 \mathrm{OHCHCl})$ and wait 5 to 10 minutes for the reduction of any $\mathrm{Fe}$ (III) to be completed. Add $10 \mathrm{~mL}$ of $0.1 \%$ 1,10- phenanthroline solution, dilute to the mark with water and mix thoroughly. Allow 10 minutes for the reddish-orange color to develop completely. Measure the absorption spectrum of this iron standard between $700 \mathrm{~nm}$ and $400 \mathrm{~nm}$. From the absorption spectrum, select the optimum wavelength to use for all subsequent absorbance measurements (Waldvogel-Abramowski. S. et al,2014) (17).

Phosphate was determined according to SMWW. Ammonium molybdate and potassium antimony tart rate react in acid medium with orthophosphate to form a heteropoly acid, phosphomolybdic acid that is reduced to intensely colored molybdenum blue by ascorbic acid. This color was measured spectrophotometrically at wavelength $880 \mathrm{~nm}$ by using a spectrophotometer (Cecil 2040, Perkin Elmer Co, Germany) (APHA, 2005).Phosphate is only measured in drums where it is injected.

Ammonia estimation by UV $\times$ Determination of ammonium by spectrophotometer. Prepare a standard iron solution containing about $0.0500 \mathrm{~g}$ of iron per $500 \mathrm{~mL}$ by first calculating the required amount of pure ferrous ammonium sulfate [Fe(NH4)2(SO4)2C6H2O] dissolve this in about $200 \mathrm{~mL}$ of demonized water containing 5.0 mLof $6 \mathrm{M} \mathrm{H} 2 \mathrm{SO} 4$ in a $500-\mathrm{mL}$ volumetric flask. Dilute with water to the mark and mix, transfer about $50 \mathrm{~mL}$ of this stock solution to a labeled plastic, transfer $5.00 \mathrm{~mL}$ of this standard iron solution to a 100-mLvolumetric flask. Add 10 $\mathrm{mL}$ of acetate buffer $\left(5.0 \mathrm{M} \mathrm{HC} 2 \mathrm{H}_{3} \mathrm{O}_{2}, 0.5 \mathrm{M} \mathrm{NaC} \mathrm{H}_{3} \mathrm{O}_{2}\right)$. Add $10 \mathrm{~mL}$ of freshly prepared $10 \% \mathrm{w} / \mathrm{v}$ hydroxylamine hydrochloride $(\mathrm{NH} 2 \mathrm{OHCHCl})$ and wait 5 to 10 minutes for the reduction of any $\mathrm{Fe}(\mathrm{III})$ to be completed. Add $10 \mathrm{~mL}$ of $0.1 \% 1$,10phenanthroline solution, dilute to the mark with water and mix thoroughly absorption spectrum of this iron standard between $700 \mathrm{~nm}$ and $400 \mathrm{~nm}$. From the absorption spectrum (American Public Health Assoc. ,et al, 1999) (18).

B.O.D was determined by. Place the desired volume of distilled water. Add $1 \mathrm{~mL}$ of phosphate buffer, magnesium sulphate solution, calcium chloride solution and ferric chloride solution for every liter of distilled water. Seed the sample with 1-2 mL of settled domestic sewage. Highly alkaline or acidic samples should be neutralized to $\mathrm{pH}$ 7. Take the sample in the required concentration. Add the required quantity of sample (calculate for $650 \mathrm{~mL}$ dilution water.). Add the dilution water up to the 
$650 \mathrm{~mL}$ mark. Mix the contents in the measuring cylinder. Add this solution into two B.O.D. bottles, one for incubation and the other for. Determination of initial dissolved oxygen in the mixture. Place the set of bottles to be incubated in a B.O.D. incubator for 5 days at $20^{\circ} \mathrm{C}$. Determine the dissolved oxygen content in the incubated bottles at the end of.5 days and note down the results. Calculate the B.O.D. of the given sample.

C.O.D was determined by Addition of $1 \mathrm{~g}$ mercuric sulphate and a few glass beads to $50.0 \mathrm{~mL}$ of sample, sulphuric acid to dissolve the mercuric sulphate and cool and $25.0 \mathrm{ml} 0.25 \mathrm{~N}$ potassium dichromate solutions. Add the remaining acid reagent (70 $\mathrm{mL)}$. Titrate the excess dichromate with standard ferrous ammonium sulphate. Using ferroin indicator ( 2 to 3 drops). The color change from blue green to reddish indicates the end point. Determine the chemical oxygen content (Metcalf. C, and Eddy, Q. P.,2003) (19).

\section{Results \& Discussion:}

Sludge is the main waste in water treatment plants. Utilization of it in valuable sectors as waste water treatment is adding value. The aim of this study is sludge activation and using it in improving of waste water properties for agricultural application.

The first step is determination of chemical compositions of normal and acid activated sludge by XRF (Table 1) and ICP-MS (Table 2) and its mineralogical constituents by XRD (Fig1).Nubaria Power Station for electricity production (study area) uses coagulant compounds that carry a charge opposite aluminum to form a floc of aluminum hydroxide in raw and waste water treatment. The outside treatment includes clarification, filtration, and ion exchange. So, in this study reusing of pretreatment sludge for heavy metals removal from waste water to improve water properties

Sludge was characterized in view of chemical and mineralogical analysis. XRF analysis in Table( 1) showed that the chemical composition of the raw water treatment plants(WTP) sludge included higher concentrations of alumina (A12O3), silica ( $\mathrm{SiO} 2$ ), and alkali earth oxides; calcium oxide $\mathrm{CaO}$, magnesium oxide and iron oxide (Fe2O3). The sum of $\mathrm{SiO} 2, \mathrm{Al} 2 \mathrm{O} 3$, is $50-55 \%$ and alkali earth oxides are $40 \%$ in the matrix corresponded to approximately of the total sludge constituents. These values are similar to those found by Yangue et al for the same oxides(YAGUE, A., et al, 2005) (20).

The high concentration of $\mathrm{SiO} 2$ can be attributed to the composition of the material sediment in the water treatment process and was mainly due to the presence of kaolinite(PINHEIRO, B. et al., 2014) (21). The presence of A12O3 could be related to the coagulant used in the water treatment process (alum- aluminum sulphate), which directly affected the chemical composition of the sludge. Calcium oxide $(\mathrm{CaO})$ values detected as $15 \%$ in sludge that meet the previous studies (RODRIGUEZ, N., et al., 2010) (22).These results indicate that the chemical characteristics of different 
WTP sludge can be related plant site geological characteristics and to the coagulant used in the water treatment process adopted by the WTP.

The presence of alkaline oxides as $\mathrm{K} 2 \mathrm{O}$, alkaline earth metals $(\mathrm{MgO}$ and $\mathrm{CaO})$, titanium oxide ( $\mathrm{TiO} 2)$, and phosphorus pent oxide (P2O5) were due to the use of coagulants in the water treatment process and the water composition (VIEIRA, C., et al., 2008) (23)., which contained suspended materials as sand and clay particles. With regards to the high value of $\mathrm{Fe} 2 \mathrm{O} 3$, this could be related to the presence of goethite (iron hydroxide $(\mathrm{FeO}(\mathrm{OH}))$ and hematite (iron oxide (Fe2O3) in the sludge which is considered pozzolanic materials. The effect of acid on alkaline and earth oxides is obviously observed as shown in table1. All concentrations are decreased with increase of acid concentration. Increase of phosphorous and titanium oxides with acid addition may be due to precipitation more stable phases in acid medium. The $\mathrm{TiO} 2$ suspended in the $\mathrm{HCl}$ media is predominant anatase in uniform cluster while the $\mathrm{TiO} 2$ deposited in the sedimentation is predominant rutile in the rod-like structure(PINHEIRO, B ., et al 2010) (24).

XRD reflected crystalline nature and phases of sludge. Quartz minerals (SiO2), goethite $[\mathrm{FeO}(\mathrm{OH})]$, and rutile $(\mathrm{TiO} 2)$, and clay minerals from the kaolinite [A12Si2O5(OH)4] group, which was the main clay mineral found in the WTP sludge in addition to its carbonaceous nature. Mineralogical composition of sludge is similar to the clay from the plant treatment region. These analyses enhanced using of sludge in waste water treatment( VIEIRA, C ., et al 2010) (25).

Table(1):XRF(raw sludge, 1,2,4NHCLactivated sludge)

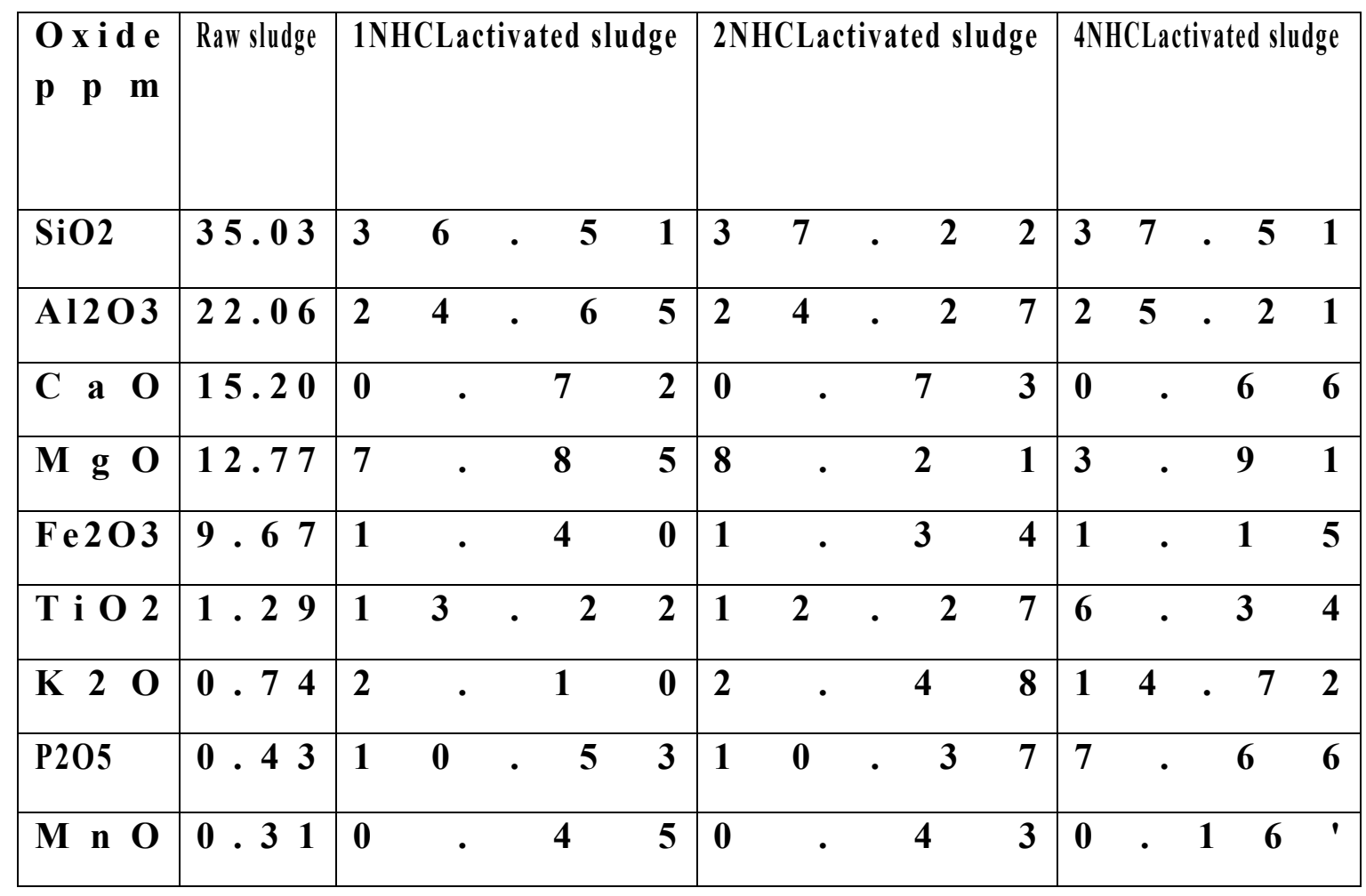




\begin{tabular}{|lll|lll|llll|llllll|lllll|}
\hline S & $\mathbf{r}$ & $\mathbf{O}$ & $\mathbf{0}$ &. & $\mathbf{1}$ & $\mathbf{1}$ & $\mathbf{0}$ & $\cdot$ & $\mathbf{3}$ & $\mathbf{3}$ & $\mathbf{0}$ & $\cdot$ & $\mathbf{3}$ & $\mathbf{1}$ & $\mathbf{1}$ & $\mathbf{8}$ & $\cdot$ & $\mathbf{7}$ & $\mathbf{0}$ \\
\hline
\end{tabular}

Fig 1:XRD(raw sludge, 1,2,4NHCLactivated sludge)

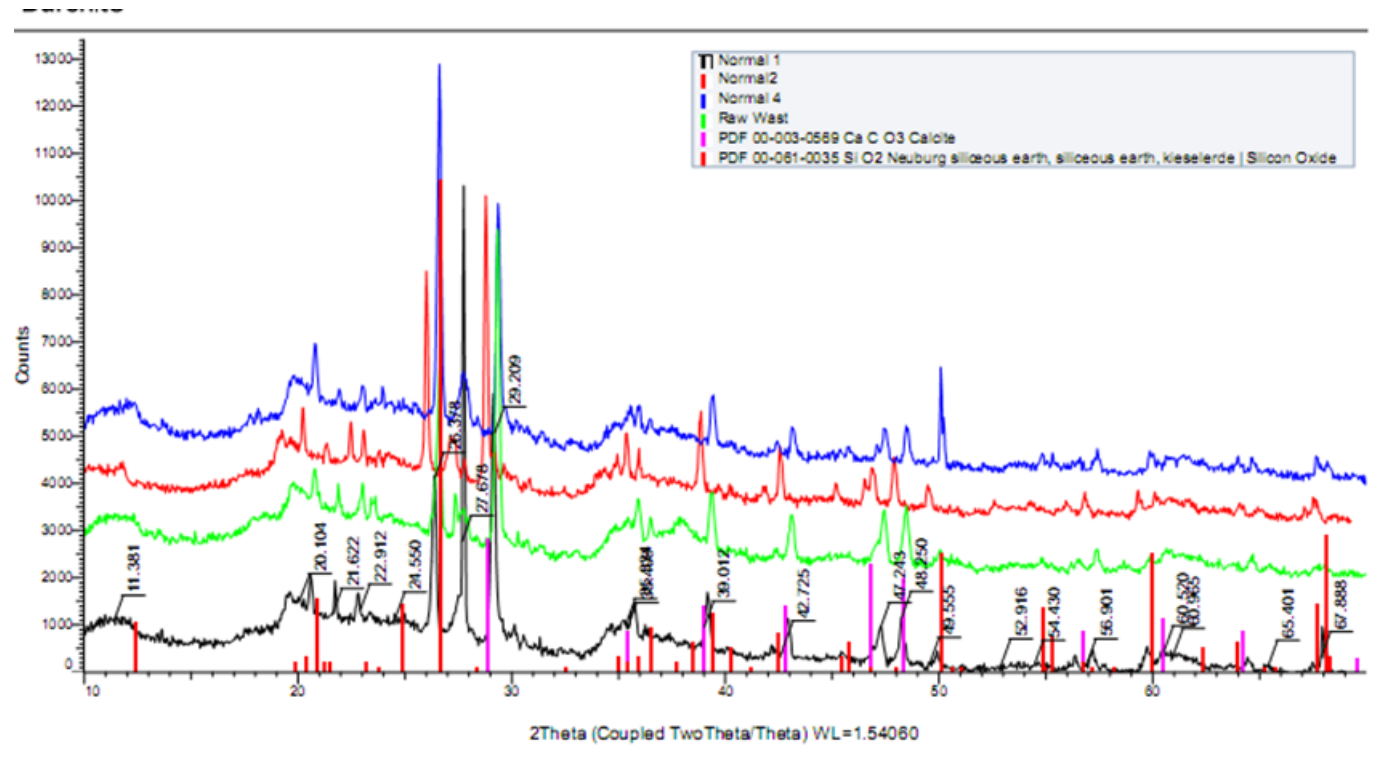

Table (2): Effect of raw sludge addition dosage (WTPS) on properties of waste water.

\begin{tabular}{|c|c|c|c|c|c|c|c|c|c|c|}
\hline $\begin{array}{l}\text { Samples } \\
\text { g/litre }\end{array}$ & $\begin{array}{l}\text { COD } \\
\text { ppm }\end{array}$ & $\begin{array}{l}\text { BOD } \\
\text { ppm }\end{array}$ & $\begin{array}{l}\text { Turbidity } \\
\mathrm{N} \text { T U }\end{array}$ & $\begin{array}{l}\text { Conductivity } \\
\mathrm{M} \mathrm{s} \mathrm{/} \mathrm{c} \mathrm{m}\end{array}$ & $\begin{array}{l}\text { TDS } \\
\text { p p m }\end{array}$ & $\mathrm{pH}$ & $\begin{array}{l}\mathrm{F} \text { e }+3 \\
\mathrm{p} \quad \mathrm{p} \mathrm{m}\end{array}$ & $\begin{array}{l}\text { A } L+3 \\
p \quad p \quad m\end{array}$ & $\begin{array}{l}\text { Ammonia } \\
\mathrm{p} \quad \mathrm{p} \text { m }\end{array}$ & $\begin{array}{l}\text { Phosphate } \\
\text { p p m }\end{array}$ \\
\hline W a s t e & $\mid Y \Lambda, V$ & $\vee \wedge, \varepsilon$ & 2.78 & $\begin{array}{llll}1 & 2 & 7 & 8\end{array}$ & 830.7 & 9.27 & $1,79 \vee 7$ & 0.18972 & $1,7 r$ &., $.9 r$ \\
\hline 1 & 126 & 71 & 1.74 & $\begin{array}{llll}1 & 0 & 6 & 9\end{array}$ & 694.85 & 9.2 & 1.45398 & 0.17792 & 1.58 & 0.089 \\
\hline 2 & 199 & $\begin{array}{ll}59 \\
\end{array}$ & 1.62 & 10 & 687.7 & 9.17 & 1.39882 & 0.16934 & 1.56 & 0.084 \\
\hline 3 & 106 & 54 & 1.53 & $\begin{array}{llll}1 & 0 & 4 & 7\end{array}$ & 676.65 & 9.18 & 1.37645 & 0.16136 & 1.47 & 0.081 \\
\hline 4 & $\begin{array}{ll}99 \\
\end{array}$ & 49 & 1.41 & $\begin{array}{llll}1 & 0 & 4 & 1\end{array}$ & 676.6 & 9.03 & 1.28842 & 0.15578 & 1.42 & 0.078 \\
\hline 5 & 83 & 37 & 1.07 & $\begin{array}{llll}1 & 0 & 2 & 6\end{array}$ & 720.85 & 8.9 & 0.092673 & 0.118492 & 1.39 & 0.075 \\
\hline
\end{tabular}




\begin{tabular}{|c|c|c|c|c|c|c|c|c|c|c|}
\hline 1 & 102 & 63 & 1.82 & $\begin{array}{lll}1 & 1 & 0\end{array}$ & 720.8 & 9.14 & 1.39174 & 0.13946 & 1.47 & 0.083 \\
\hline 1 & 119 & 69 & 2.06 & 132 & 859.95 & 9.17 & 1.47365 & 0.14241 & 1.54 & 0.087 \\
\hline 2 & 125 & 74 & 2.56 & 13 & 899.6 & 9.25 & 1.58364 & 0.16272 & 1.59 & 0.089 \\
\hline Irrigation & 30.1 & 11.7 & 0.77 & 3 & 610.3 & 8.1 & 0.1734 & 0.3412 & 1.02 & 0.0378 \\
\hline Permissible levels & 100 & 6 & 1 & 15 & 1000 & $8.5-6.5$ & 1 & 0 & 1 & 1 \\
\hline
\end{tabular}

It was found in table (2) that the best addition of normal sludge for waste water treatment was $5 \mathrm{~g}$ for $1 \mathrm{~L}$.

Table(3): Effect of water treatment plant sludge(WTPS) in waste water treatment, due to using of acid activated sludge ( $1 \mathrm{~N}$ HCL ) in waste water treatment for heavy removal and treatment.

\begin{tabular}{|c|c|c|c|c|c|c|c|c|c|c|}
\hline Samples & $\begin{array}{l}\text { C O D } \\
\text { p p m }\end{array}$ & $\begin{array}{l}\text { B O D } \\
\text { p p m }\end{array}$ & $\begin{array}{l}\text { Turbidity } \\
\mathrm{N} T \mathrm{~T}\end{array}$ & $\begin{array}{l}\text { Conductivity } \\
\mathrm{M} \mathrm{s} \mathrm{/} \mathrm{c} \mathrm{m}\end{array}$ & $\begin{array}{l}\text { T D S } \\
\text { p p m }\end{array}$ & $\mathrm{pH}$ & $\begin{array}{l}\mathrm{Fe}+3 \\
\mathrm{p} \mathrm{p} \mathrm{m}\end{array}$ & $\begin{array}{l}A L+3 \\
p p m\end{array}$ & $\begin{array}{l}\text { Ammonia } \\
\mathrm{p} \mathrm{p} \mathrm{m}\end{array}$ & $\begin{array}{l}\text { Phosphate } \\
\text { p p m }\end{array}$ \\
\hline Waste & 128.7 & 78.4 & 7 & 2 & 830.7 & 9.27 & 1.6976 & $\cdot, 1 \wedge 9 \vee$ & 1.62 & 0.093 \\
\hline $\mathrm{g}$ & 89.2 & 62.2 & 41.3 & $\begin{array}{lll}1 & 0 & 7\end{array}$ & 696.8 & 9.24 & 1.2978 & 0.1264 & 1.52 & 0.076 \\
\hline $\mathrm{g}$ & 56.7 & 35.1 & 5.8 & $\begin{array}{llll}1 & 0 & 3 & 8\end{array}$ & 674.7 & 9.13 & 0.5941 & 0.0892 & 1.26 & 0.062 \\
\hline $\mathrm{g}$ & 36.4 & 13.4 & 1.09 & $\begin{array}{llll}1 & 0 & 0 & 8\end{array}$ & 655.2 & 8.6 & 0.1351 & 0.0641 & 1.13 & 0.043 \\
\hline $\mathrm{g}$ & 42.6 & 37.3 & . 7 & $\begin{array}{llll}1 & 2 & 3 & 3\end{array}$ & 801.4 & 8.9 & 1.1603 & 0.093517 & 1.19 & 0.056 \\
\hline $\mathrm{g}$ & 49.3 & 52.2 & $\begin{array}{lll}3 & 1.9\end{array}$ & $\begin{array}{llll}1 & 2 & 6 & 2\end{array}$ & 820.3 & 9.19 & 1.2114 & 0.0992 & 1.38 & 0.071 \\
\hline 0 & 96.5 & 64.6 & 43.1 & 143 & 930.8 & 9.22 & 1.3983 & 0.1078 & 1.44 & 0.075 \\
\hline
\end{tabular}




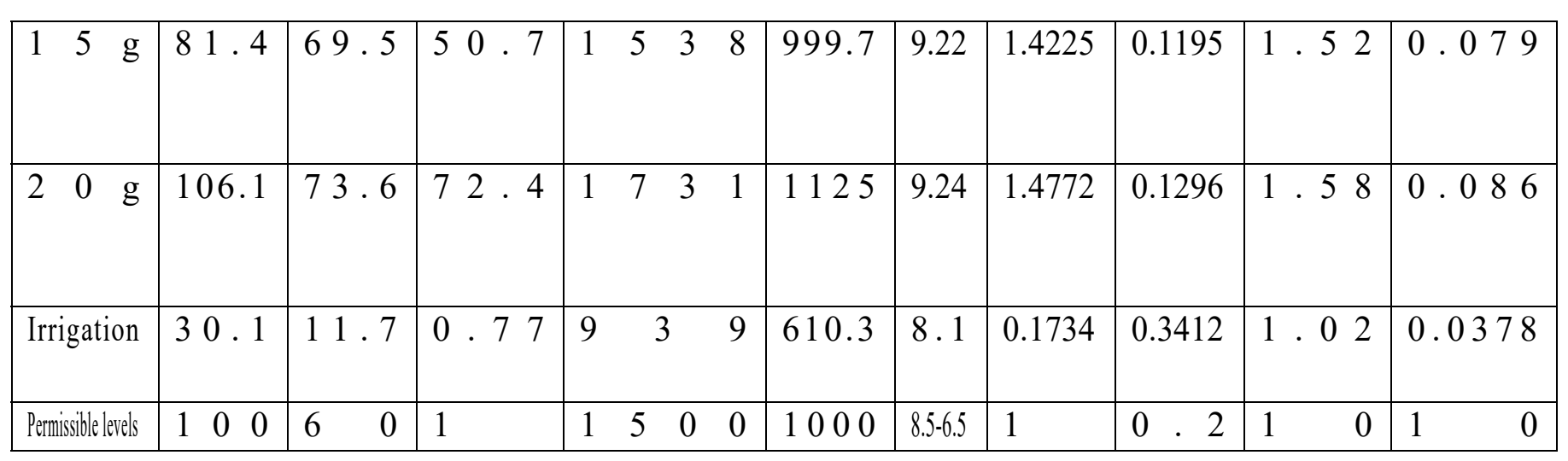

It was found in table(3) that the best effect of water treatment plant sludge(WTPS) in waste water treatment, due to using of acid activated sludge ( $1 \mathrm{~N} \mathrm{HCL}$ ) in waste water treatment for heavy removal and treatment was $3 \mathrm{~g}$ for $1 \mathrm{~L}$.

Table (4): Effect of water treatment plant sludge (WTPS) in waste water treatment due to using of activated sludge $(2 \mathrm{~N}, \mathrm{HCl})$ in waste water treatment for heavy removal and treatment.

\begin{tabular}{|c|c|c|c|c|c|c|c|c|c|c|}
\hline Samples & $\begin{array}{l}\text { C O D } \\
p \quad p \quad m\end{array}$ & $\begin{array}{lll}\text { B } & \text { O } & \text { D } \\
p & p & m\end{array}$ & $\begin{array}{l}\text { Turbidity } \\
\mathrm{N} \text { T U }\end{array}$ & $\begin{array}{l}\text { Conductivity } \\
\mathrm{M} \mathrm{s} \mathrm{/} \mathrm{c} \mathrm{m}\end{array}$ & $\begin{array}{l}\text { T D S } \\
\text { p p m }\end{array}$ & $\mathrm{p} \mathrm{H}$ & $\begin{array}{l}\mathrm{Fe}+3 \\
\mathrm{p} \mathrm{p} \mathrm{m}\end{array}$ & $\begin{array}{l}A L+3 \\
p p m\end{array}$ & $\begin{array}{l}\text { Ammonia } \\
\mathrm{p} \mathrm{p} \mathrm{m}\end{array}$ & $\begin{array}{l}\text { Phosphate } \\
\text { p p m m }\end{array}$ \\
\hline Waste & 128.7 & 78.4 & $\begin{array}{lll}2 & 7 & 8\end{array}$ & $\begin{array}{llll}1 & 2 & 7 & 8\end{array}$ & 830.7 & 9.27 & 1.6976 & $\cdot, 1 \wedge 9 \vee$ & 1.62 & 0.093 \\
\hline $\mathrm{g}$ & 87.6 & 58.6 & 37.2 & $\begin{array}{llll}1 & 0 & 5 & 7\end{array}$ & 687.05 & 9.19 & 1.1865 & 0.1179 & 1.48 & 0.067 \\
\hline g & 52.7 & 33.9 & 3.9 & $\begin{array}{llll}1 & 0 & 2 & 2\end{array}$ & 664.3 & 9.06 & 0.4839 & 0.0785 & 1.23 & 0.059 \\
\hline $\mathrm{g}$ & 29.3 & 9.8 & 0.94 & 86 & 640.9 & 8.3 & 0.1183 & 0.0594 & 1.08 & 0.038 \\
\hline $\mathrm{g}$ & 38.1 & 34.2 & . 1 & $\begin{array}{llll}1 & 2 & 2 & 7\end{array}$ & 797.55 & 9.14 & 1.1858 & 0.0843 & 1.15 & 0.0551 \\
\hline $\mathrm{g}$ & 44.7 & 50.3 & 27.5 & $\begin{array}{llll}1 & 2 & 3 & 9\end{array}$ & 805.35 & 9.17 & 1.1965 & 0.0898 & 1.31 & 0.069 \\
\hline 10 & 90.2 & 57.8 & $36 \cdot 1$ & $\begin{array}{llll}1 & 4 & 3 & 2\end{array}$ & 930.8 & 9.19 & 1.3287 & 0.0973 & 1.38 & 0.072 \\
\hline $\begin{array}{lll}1 & 5 & \mathrm{~g}\end{array}$ & 91.4 & 62.5 & 45.3 & $\begin{array}{llll}1 & 5 & 1 & 8\end{array}$ & 986.7 & 9.21 & 1.3986 & 0.1227 & 1.46 & 0.074 \\
\hline
\end{tabular}




\begin{tabular}{|c|c|c|c|c|c|c|c|c|c|c|}
\hline $\begin{array}{lll}2 & 0 & \mathrm{~g}\end{array}$ & 97.3 & 69.1 & 69.1 & 17 & 1105.6 & 9.22 & 1.4662 & 0.1297 & 1.51 & 0.080 \\
\hline Irrigation & 30.1 & 11.7 & 0.77 & $\begin{array}{ll}3 & 9\end{array}$ & 610.3 & 8.1 & 0.1734 & 0.3412 & 1.02 & 0.0378 \\
\hline Permissiblel levels & 100 & 6 & 1 & $\begin{array}{llll}1 & 5 & 0 & 0\end{array}$ & 1000 & $8.5-6.5$ & 1 & 0.2 & 1 & 1 \\
\hline
\end{tabular}

It was found in table(4 ) that the best effect of water treatment plant sludge(WTPS) in waste water treatment due to using of activated sludge $(2 \mathrm{~N} \mathrm{HCl})$ in waste water treatment for heavy removal and treatment is $(3 \mathrm{~g}$ for $1 \mathrm{~L})$.

Table(5):Effect of water treatment plant sludge(WTPS) in waste water treatment due to using of activated sludge ( $4 \mathrm{~N}$ HCL) in waste water treatment for heavy removal and treatment.

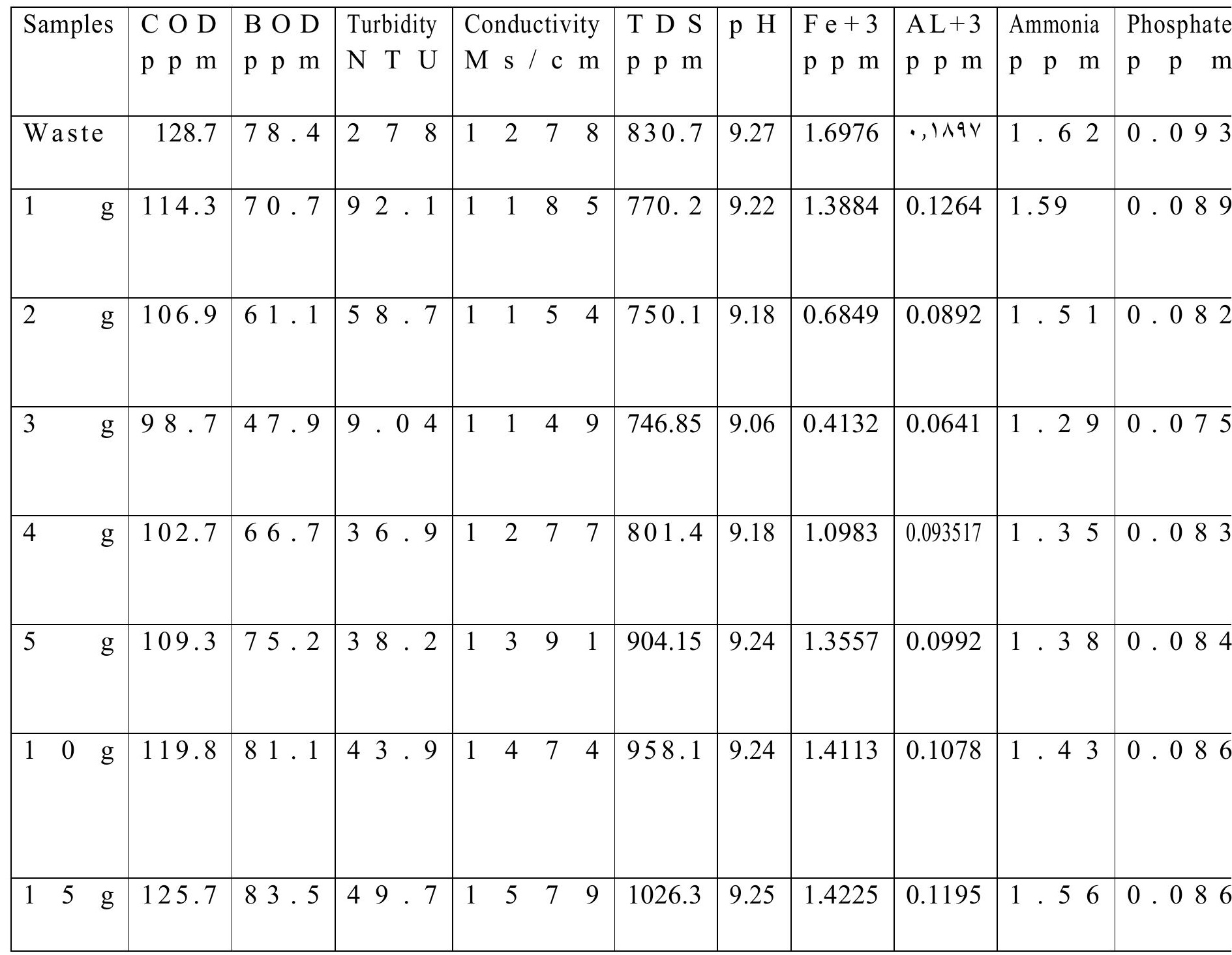




\begin{tabular}{|c|c|c|c|c|c|c|c|c|c|c|}
\hline $\begin{array}{lll}2 & 0 & \mathrm{~g}\end{array}$ & 128.4 & 88.4 & 65.6 & $\begin{array}{llll}1 & 7 & 6 & 3\end{array}$ & 1145.9 & 9.27 & 1.4772 & 0.1296 & 1.61 & 0.087 \\
\hline Irrigation & 30.1 & 11.7 & 0.77 & 9 & 610.3 & 8.1 & 0.1734 & 0.3412 & 1.02 & 0.0378 \\
\hline Permissible levels & $\begin{array}{lll}1 & 0 & 0\end{array}$ & 6 & 1 & $\begin{array}{lll}1 & 5 & 0\end{array}$ & 1000 & $8.5-6.5$ & 1 & 0.2 & 1 & 1 \\
\hline
\end{tabular}

It was found in table(5 ) that the best effect of water treatment plant sludge(WTPS) in waste water treatment due to using of activated sludge ( $4 \mathrm{~N}$ HCL) in waste water treatment for heavy removal and treatment is( $3 \mathrm{~g}$ for $1 \mathrm{~L})$.( Food and Agriculture Organization.,1985)(26) .

Normal and acid activated sludge have positively effect in improving of treated waste water properties as shown in the results. Activation of sludge affected on their particles properties; size, structure and density that leads to increase of; surface area and adsorption efficiency. (Liao, B.,et al, 2006) (27).

As shown in Tables (2-5), $\mathrm{pH}$ decreased from 9.6 to 8.3 then raised to 9; with addition of raw or acid activated sludge. This may be attributed to many causes. Firstly; the effectiveness of aluminum coagulants arises principally from their ability to form multi-charged poly nuclear complexes with enhanced adsorption characteristics. These complexes may be controlled by the $\mathrm{pH}$ of the system. The second factor may be presence of higher molecular weight humic acids that tend to be easier to remove; aluminum coagulants added to water hydrolyze to form aluminum hydroxide with a net positive charge. This net positive charge is a function of $\mathrm{pH}$. As the $\mathrm{pH}$ decreases, the number of positively charged sites on the aluminum hydroxide particles increases (Viraraghavan, T. and Wimmer, C. ,1988) (28).Aluminum ions from $\mathrm{Al}_{2}\left(\mathrm{SO}_{4}\right)_{3}$ are surrounded by water molecules, becoming $\mathrm{Al}\left(\mathrm{H}_{2} \mathrm{O}\right)_{6}{ }^{+3}$, where hydrogen ions $(\mathrm{H}+)$ react with alkalinity in water. The $\mathrm{Al}(\mathrm{OH})_{3}$ is main factor to decreases $\mathrm{pH}$ and alkalinity. In chemical coagulation, the floc quantity is determined by the charge density. The larger the algae cell size, the more floc is required for efficient chemical coagulation. (WHO, 2015) (29).

Biochemical oxygen demand (BOD) represents the amount of oxygen consumed by bacteria and other microorganisms while they decompose organic matter under aerobic (oxygen is present) conditions at a specified temperature.COD (chemical oxygen demand) indicates all oxidizable materials but provides no information on their biodegradability.

As shown in Tables (2-4), BOD as well as COD decreased from78/129 to 30/10 with addition of raw or acidified sludge till $2 \mathrm{~N} \mathrm{HCl}$ while the effect of $4 \mathrm{~N} \mathrm{HCl}$ is 500/100, table 5.This may be attributed to complex interaction between the clay minerals and the organic matters. The values and ratio of BOD/COD decreased in a 
process which involves the roles of silicate layers, inorganic cations and the organic molecules. These complexes are between the organic matter and the clay minerals leading to cation or anion exchange (Mortland, M.,1970)( 30).As illustrated in this present results. Ratio decreased from 0.6 to 0.3 with sludge addition except the forth case $4 \mathrm{~N} \mathrm{HCl}$, table 5. The COD / BOD ratio help to qualify the biodegradability of effluent; COD / BOD $<2$ means readily biodegradable effluent;2 $<$ COD / BOD $<4$ : moderately biodegradable effluent; while $\mathrm{COD} / \mathrm{BOD}>4$ : hardly biodegradable effluent.Cation exchange describes the adsorption of the organic cations by the clay minerals with the inorganic cations leaving. The interaction of positive charge sites, at oxide surfaces or edge sites of clays with carboxylate $\left(\mathrm{COO}^{-}\right)$, sulfonate $\left(\mathrm{SO}^{3-}\right)$, and phenolate (aromatic $\mathrm{O}^{-}$) groups, is by replacement of univalent exchangeable anions (e.g., $\mathrm{Cl}^{-}$or $\mathrm{NO}^{3-}$ ) bound to a protonated surface hydroxyl. The acidity of the clay surface is the main factor causing the organic compound to be in cationic form. On the other hand, the presence of the metal oxides at clay fractions can make this mechanism complete

(Rosen,Mand.;Kunjappu,J.,2012)(

$31)$.

\section{Ammonia}

Ammonia decreased by $14-33 \%$ with addition of sludge, tables (2-4) and $20 \%$ table 5.Ammonia was removed from waste waters by clay minerals. One of the advantages of using clays as the adsorbent for ammonia removal is that the layered structure of the clay allows expansion (swelling) when in contact with water, which exposes an additional mineral surface capable of ammonium ion $\left(\mathrm{NH}^{4+}\right)$ adsorption . (Aziz, S.,et al, 2010) (32).Specific surface area (SSA), cation exchange capacity (CEC), and the functional groups of the different fractions of soils are the surface characteristics of the soil solids. Some exchangeable cations, such as $\mathrm{K}^{+}, \mathrm{Na}^{+}, \mathrm{Mg}^{2+}$, and $\mathrm{Ca}^{2+}$, are available in the structure of clayey molecules, and these cations can easily exchange with other cations such as $\mathrm{NH}^{4+}$. The stage of the cation in the lyo tropic series, concentration of the cations, and the diameter of the cation molecule ar the effective factors in the ion exchange mechanism(Renou, S.,et al, 2008) (33).

\section{Heavy metals}

Heavy metals; $\mathrm{Al}+3$ and $\mathrm{Fe}+3$, reduction is observed in this study. These uptake of them is up to $75 \%$ to $95 \%$ respectively as shown in tables (2-5). The adsorption of $\mathrm{Al}+3$ and $\mathrm{Fe}+3$ by sludge is based on exchange reactions, complexation with negatively charged groups, adsorption and precipitation. The equilibrium between an adsorbate immobilized on and adsorbents and the adsorbate remaining in aqueous phase is usually presented by adsorption isotherms. The adsorption efficiency increased rapidly within the first $30 \mathrm{~min}$ and then slowed, approaching a steady state after $5 \mathrm{~h}$. After this equilibrium period, the amount of adsorbed metal ions did not change(You,S.,etal,2009) 


\section{Turbidity}

Using of sludge established the permissible value of turbidity (1 NTU) where it was improved till 99\%; as shown in Tables (2-5). As the turbidity removal continues to be a prime objective of coagulation operation. With the addition of coagulants, turbidity can be removed and clear water may be obtained. Higher efficiency to treat turbid water has made inorganic chemicals favorite coagulants. In water, aluminum salts hydrolyze and give a variety of products including cationic species, which can absorb on negative charged particles, and thus neutralize their charge. The particles get destabilized and aggregation occurs. Over dozing of coagulant leads to charge reversal and particles start re-stabilizing. A higher than the optimum dose of coagulant thus results in less turbidity removal. Alum exhibits a different behavior compared to other coagulants. (Choy, S,Y.,2016) (35).

\section{Phosphate}

Phosphate uptake is $19-60 \%$ with addition of raw sludge and acidified with $1 \mathrm{~N}$ and $2 \mathrm{~N}, \mathrm{HCl}$ as shown in Tables (2-4); while at $4 \mathrm{~N}, \mathrm{HCl}$ the uptake is $19 \%$, Table 5. This may be attributed to interaction of reagent ions with soluble salts of the orthophosphoric acid, with creating highly dispersed colloid phosphate sediment. Meanwhile, the chemical reacts with water-borne bases to produce large-flake sediment. This sediment triggers coagulation of the high-dispersion colloid phosphate sediment and suspension, it also adsorbs some of the phosphorus-bearing organic compounds, and then it is withdrawn from the system. Salts of two- and three-valent metals are used as reagents (Shourian, M. . ,et al, 1999) (36).

Adding aluminum sulfate to waste water in the presence of alkali produces the following reaction:

$\mathrm{Al}_{2}\left(\mathrm{SO}_{4}\right)_{3}+6 \mathrm{HCO}^{3-} \rightarrow 2 \mathrm{Al}(\mathrm{OH})_{3}+3 \mathrm{SO}_{4}{ }^{2-}+6 \mathrm{CO}_{2}$ Further on, the following reaction occurs in the presence of phosphates: $\mathrm{Al}_{2}\left(\mathrm{SO}_{4}\right)_{3} \cdot 14 \mathrm{H}_{2} \mathrm{O} \quad+\quad 2 \mathrm{PO}_{4}{ }^{3} \rightarrow 2 \mathrm{AlPO}_{4}+\quad 3 \mathrm{SO}_{4}{ }^{2-}+14 \mathrm{H}_{2} \mathrm{O}$ These two reactions compete for aluminum ions, created by adding the reagent aluminum sulfate. The flakes of aluminum hydroxide sediment absorb aluminum phosphates and colloid particles of solid impurities, thus helping to remove phosphorus by clearing out the wastewater(Yang, Sh. et al, 2017) (37).

At the lower dosing of sludge, the formation of $\mathrm{AlPO}_{4}$ is predominant. When the phosphates in the wastewater have been precipitated, the excess alum results in the formation of hydroxides. This is responsible for the disintegration of the overall floc structure at resulting in the drop in sludge Velocity and increase in the sludge settle ability.
$\mathrm{Al}^{3+}+3 \mathrm{H}_{2} \mathrm{O}$
$\rightarrow \quad \mathrm{Al}(\mathrm{OH})_{3}$
$+$
$3 \mathrm{H}^{+}$
$\mathrm{Al}^{3+}+\mathrm{PO}_{4}^{3}-\rightarrow \mathrm{AlPO}_{4}$

Decreasing sludge efficiency at the higher dosing of sludge; are attributed surface charge reversal linked to high aluminum dosing rate and high surface charge which is 
a function of weaker bonding between the various sludge floc fractions resulting to the breakage of the general activated sludge floc structure. (Rittmann, B. and Laspidou, C. , 2002) (38). Aluminum sludge reduces the issues of extending filamentous organisms over floc forming bacteria in the entire sludge particle surface(interfloc bridging), set along extended filamentous, floc bacteria tends to settle as a zone of blanket (sludge blanket), accounting for the decrease in the settling velocity of the sludge flocs and increasing sludge concentration( Sheng, G., et al, 2010) (39). This behavior and effect of dosage ratio can be applied in case of all cations removal as ammonia and iron.

\section{Conductivity and TDS}

Conductivity is related to total dissolved salts (TDS). As shown in Table (5), conductivity and TDS increased together with $8 \%$ approximately. As significant sources of TDS and conductivity increase during the biological treatment is generation of inorganic salts (ammonium, nitrates, sulfates, orthophosphates) from biodegraded volatile suspended solids and release of metabolic byproducts by bacteria. Alkalinity (bicarbonate) consumption during nitrification will complicate these effects, but it was observed in Tables (2-4), conductivity and TDS decreased. The influence of mixed salt solutions percolation on the media that elevated exchangeable sodium levels at low concentrations cause dispersion and swelling of the clay minerals and consequently a reduction in hydraulic conductivity of the water solution, conductivity was related to TDS. During activated sludge treatment, the major process impacting TDS is the degradation of soluble organics, which are either incorporated into the biomass or released as $\mathrm{CO} 2$ and mostly stripped. When alkali is added, as frequently is the case when nitrifying, the released $\mathrm{CO} 2$ could be captured and converted to bicarbonates, and these will convert back to carbonates during TDS determination. During the nitrification step bicarbonate is in turn a source of carbon for growth of nitrifies, de-nitrification, due to the release of alkalinity will have minor effect on the effluent TDS(Abu-Sharar et al., 1987) (40).

\section{Conclusion:}

It was found that the best addition of normal sludge for waste water treatment was $5 \mathrm{~g} / \mathrm{lt}$. The best effect of water treatment plant sludge (WTPS) in waste water treatment, due to using of acid activated sludge ( $1 \mathrm{~N} \mathrm{HCL}, 2 \mathrm{~N} \mathrm{HCl}$ ) in waste water treatment was $3 \mathrm{~g}$ for $1 \mathrm{~L}$.

\section{Recommendation:}

The use of raw water clarification sludge was the best compensation to get suitable COD, BOD, Turbidity, conductivity, TDS, pH, Ammonia, Phosphate and heavy metals removal in waste water. 


\section{REFRENCES:}

1.Gerbens, D.,Prakhar, P.E. and Arup, K.S., 1998 "Donnan Membrane Process: Principles \&Application in Coagulant Recovery from Water Treatment PlantResiduals", Lehigh University, Bethlehem, PA 18015.

2.Blakemore, R., Chandler, R., Surrey, T., Ogilvie, D., Walmsley, N., 1998. Management of Water Treatment Plant Residuals in New Zealand, first ed. Water Supply Managers' Group, New Zealand Water and Wastes Association, Auckland, pp. 56.

3.Deng Y, Zhao R(2015): Advanced oxidation processes (AOPs) in wastewater treatment. Curr Pollution Rep, 1:167-176 http://dx.doi.org/10.1007/s40726-015-0015$\mathrm{Z}$.

4.Tchobanoglous G,M.\& E. Inc, Burton FL, Stensel HD(2012): WastewaterEngineering: Treatment and Reuse. 4th edition. Boston: McGrawHill Higher Education.

5. Diamantis, v ;erguder, th; aivasidis, a; verstraete, w; voudrias e(2018); Waste water disposal to landfill-sites: asynergistic solution for centralized management of olive mill waste water and enhanced production of landfill gas . j. environ. Manag. 128, $427-434$

6. Rosen, M.J.; Kunjappu, J.T. Surfactants and Interfacial Phenomena; John Wiley \& Sons: Hoboken, NJ, USA, 2012.

7.Maiden, P., Hearn, M.T.W., Boysen, R.I. Chier, P., Warnecke, M., Jackson, W.R. 2015. Alum sludge re-use investigation (10OS-42) prepared by GHD and Centre for Green Chemistry (Monash University) for the Smart Water Fund, Victoria, ACTEW Water \&Seqwater.

8.Ruiz-Rosa I, Garcí a-Rodrí guez FJ, Mendoza-Jime' nez J(2015):Development and application of a cost management model forwastewater treatment and reuse processes. J Clean Prod 2016,113:299-310 http://dx.doi.org/10.1016/j.jclepro. 12.044.

9. Liu C-Z, Li A-H, Klemes` JJ, Liu Z-Y(2018): Design of distributed wastewater treatment networks by combining total mixing influence potential indicator with heuristic rules. J Clean Prod, 193:604-613 http://dx.doi.org/10.1016/j. jclepro.2018.05.016.

10. DegaardH(2014): Optimization of flocculation/flotation in chemical wastewater treatment. Water SciTechnol, 31:73-82 http:// dx.doi.org/10.1016/02731223(95)99878-8.

11. Soulsby RL, Manning AJ, Spearman J, Whitehouse RJS(2017): Settling velocity and mass settling flux of flocculated estuarine sediments. Mar Geol 2013, 339:1-12 http://dx.doi.org/10.1016/j. margeo.2013.04.006. 
12. Benidickson, J. I.and, Beychok, M.R. (2011). "Performance of surface-aerated basins".Chemical Engineering Progress Symposium Series. 67 (107): 322-339. Available at Series.

13. Ghosh A, Dastidar MG, Sreekrishnan, TR,2016 Recent advances in bioremediation ofheavy metals and metal complex dyes: Review. J. Environ. Eng.;142:1-14.

14. Natarajan R, ManivasaganR. ,2016Biosorptive removal of heavy metal onto raw activated sludge: Parametric, equilibrium, and kinetic studies. J. Environ. Eng.;142:16.

15.Angin, I. and Yaganoglu, A.V. (2011) 'Effects of sewage sludge application on some physical and chemical properties of a soil affected by wind erosion', Journal of Agricultural Science and Technology, Vol. 13, pp.757-768.

16. Li.Z, Lu. N, Zhou, X. and Song, Q. (2007). Extraction spectrophotometric determination of aluminum in dialysis concentrates with 3,5-ditertbutylsalicyl fluorone and ionic liquid 1-butyl-3-trimethylsilylimidazolium ,hexafluorophosphate. J Pharma 43(5) : 1609

17. Waldvogel-Abramowski. S, Waeber. G, Gassner. C, Buser. A, Frey, B. M, Favrat. B, and Tissot, J.D. (2014). Physiology of iron metabolism.Transfus Med Hemother. Jun;41(3):213-21. doi: 10.1159/000362888.

18. American Public Health Assoc., American Water Works Assoc. \& Water Environment Federation. (1999). Standard Methods for the Examination of Water and Wastewater (20th ed.). Baltimore, MD: American Public Health Association.

19. Metcalf. C, and Eddy, Q. P.( 2003). Waste water engineering: Treatment and Reuse. 4th Edition.McGraw-Hill, NEW York, NY.

20. YAGUE, A., VALLS, S., VÁZQUEZ, E., et al., 2005. Durability of concrete with addition of dry sludge from waste water treatment plantsll, Cement and Concrete Research, v. 35, n. 6, pp. 1064-1073, jun.

21. PINHEIRO, B. C. A., ESTEVÃO, G. M., SOUZA, D. P. 2014. Lodoproveniente da estação de tratamento de água do município de Leopoldina, MG, paraaproveitamentonaindústria de cerâmicavermelha Parte I: caracte-rizaçãodolodoll, Matéria, v. 19, n. 3, pp. 204-211,

22. RODRIGUEZ, N.H., MARTÍNEZ RAMÍREZ, S., BLANCO VARELA, M.T., et al., , 2010. Re-use of drinking water treatment plant (DWTP) sludge: Characterization and technological behaviour of cement mortars with atomized sludge additions $\|$, Cement and Concrete Research, v. 40, n, 5, pp. 778-786 
23. VIEIRA, C. M., MARGEM, J.I., MONTEIRO, S.N., 2008. Alteraçõesmicroestruturais de ceramic argilosaincorporada com lodo de ETAll, Matéria, v.13, n.2, pp.275-281,

24. PINHEIRO, B. C. A., ESTEVÃO, G. M., SOUZA, D. P. , 2014. Lodoproveniente da estação de tratamento de água do município de Leopoldina, $\mathrm{MG}$, paraaproveitamentonaindústria de cerâmicavermelha Parte I: caracte-rizaçãodolodoll, Matéria, v. 19, n. 3, pp. 204-211.

25.VIEIRA, C. M., MARGEM, J.I., MONTEIRO, S.N., , 2008. Alteraçõesmicroestruturais de cerâmicaargilosaincorporada com lodo de ETAll, Matéria, v.13, n.2, pp.275-281

26.Food and Agriculture Organization.(2015). Water quality for agriculture. Irrigation and Drainage Paper 29 Rev. 1, a Adapted from University of California Committee of Consultants.

27. Liao, B.Q.; Droppo, I.G.; Leppard, G.G.; Liss, S.N, 2006. Effect of solids retention time on structure andcharacteristics of sludge flocs in sequencing batch reactors. Water Res., 40, 2583-2591.

28.Viraraghavan, T. and C.H. Wimmer, 1988.Polyaluminium chloride as an alternative to alum coagulation: A case study. Proceedings of the Annual Conference on Canadian Society for Civil Engineering, (SCE' 88), pp: 480-498.

29. WHO, 2015. Management of cyanobacteria in drinkingwater supplies: Information for regulators and water suppliers. WHO/FWC/WSH/15.03.

30. Mortland, M.M., 1970. Clay-organic complexes and interactions. Adv. Agron., 22.

31. Rosen, M.J.; Kunjappu, J.T. , 2012. Surfactants and Interfacial Phenomena; John Wiley \& Sons: Hoboken, NJ, USA.

32. Aziz, S.Q.; Aziz, H.A.; Yusoff, M.S.; Bashir, M.J.; Umar, M.,2010. Leachate characterization in semi-aerobic and anaerobic sanitary landfills: A comparative study. J. Environ. Manag., 91, 2608-2614.

33. Renou, S.; Givaudan, J.G.; Poulain, S.; Dirassouyan, F.; Moulin, P., 2008.Landfill leachate treatment: Review and opportunity. J. Hazard. Mater. 150, 468-493.

34. You SJ, Tsai YP, Huang RY (2009) Effect of heavy metals on nitrification performance in different activated sludge processes. J Hazard Mater 165, 987-94.

35.Choy SY (2016) Performance of conventional starches as natural coagulants forturbidityremoval.EcolEng

94:352-364. 
36. Shourian, M. A. Moridi, M. Kaveh, (2016). Water Sci. and Technol., 74 (6) 13761385 (2016) DOI: 10.2166/wst.2016.322.

37. Yang, Sh. P. Jin, X. C. Wang, Q. Zhang, X. Chen, (2017) Water Sci. and Technol., Available Online 10 January 2017, wst2017019; DOI: 10.2166/wst.2017.019.

38. Rittmann, B.E.; Laspidou, C.S . 2002. A unified theory for extracellular polymeric substances, soluble microbial products, and active and inert biomass. Water Res, 36, 2711-2720.

39. Sheng, G.P.; Yu, H.Q.; Li, X.Y. 2010. Extracellular polymeric substances (EPS) of microbial aggregates in biological wastewater treatment systems: A Review. Biotechnol.Adv, 28, 882-894.

40. Abu-Sharar et al., 1987; Curtin et al., 1994; AmézketaandAragües, 1995; AbuSharar and Salameh, 1995. 